\title{
MULTIVARIATE ANALYSIS FOR CLASSIFICATION OF DENDROMETRIC AND ENERGETIC VARIABLES OF Eucalyptus benthamii
}

\author{
Cristiane Carla Benin ${ }^{1}$, Luciano Farinha Watzlawick², Vanderlei Aparecido de Lima ${ }^{3}$ \\ *Universidade Estadual do Centro- Oeste, Programa de Pós-Graduação em Ciências Florestais, Guarapuava, Paraná, Brazil - \\ cristianebenin@hotmail.com \\ ${ }^{2}$ Universidade Estadual do Centro- Oeste, Professor Doutor do Departamento de Agronomia, Guarapuava- Paraná, Brazil - \\ farinha@unicentro.com.br \\ ${ }^{3}$ Universidade Técnológica Federal do Paraná., Professor Doutor do Departamento de Química, Pato Branco. Paraná, Brazil - \\ valima66@gmail.com \\ Received for publication: 13/06/2019 - Accepted for publication: 09/01/2020
}

\begin{abstract}
Resumo
Aplicação de técnicas multivariadas para classificação de variáveis dendrométricas e energéticas de Eucalyptus benthamii. O objetivo deste estudo foi avaliar dados dendrométricos e de propriedades energéticas de E. benthamii, a partir de avaliações em plantios de diferentes idades e regiões de produção, em GuarapuavaPR, por meio de análise estatística multivariada. Os dados são referentes a três regiões (R1, R2 e R3) e idades (5, 6 e 7 anos), foram submetidos às técnicas multivariadas: análise fatorial, análise dos componentes principais e análise de agrupamento hierárquico. A redução da dimensionalidade dos dados foi encontrada contendo apenas 5 atributos dos 13 iniciais, sendo eles (DAP médio, altura média, volume por hectare, densidade básica da madeira e densidade energética), associados a dois componentes principais, capazes de representar 95,22\% da variância dos dados. Os plantios da região R1 com sete anos de idade apresentaram excelentes propriedades energéticas, enquanto os plantios da região R2 com sete anos e região R3 com seis anos representam áreas mais produtivas, avaliadas pelas variáveis dendrométricas. Observou-se ainda que os plantios com maior idade e de maior densidade básica da madeira apresentam maior qualidade para uso energético. Pode-se concluir que a análise de agrupamento foi adequada para estratificar de forma eficiente regiões e idades com maior e menor produtividade, assim como as com melhores propriedades energéticas.

Palavras- chave: Técnicas multivariadas, produção florestal, grupos de similaridade.
\end{abstract}

\section{Abstract}

The objective of this study was to evaluate dendrometric data and energetic properties of E. benthamii, based on evaluations in plantations of different ages and regions of production, in Guarapuava-PR, through multivariate statistical analysis. The data refer to three regions (R1, R2 and R3) and ages (5, 6 and 7 years), were submitted to multivariate techniques: factor analysis, analysis of the main components and analysis of hierarchical grouping. The reduction in the dimensionality of the data was found containing only 5 attributes of the initial 13, which are (average DBH, average height, volume per hectare, basic density of wood and energy density), associated with two main components, capable of representing $95.22 \%$ of the data variance. The plantations in the R1 region with seven years of age showed excellent energetic properties, while the plantations in R2 region with seven years and R3 region with six years represent more productive areas, evaluated by dendrometric variables. It was also observed that plantations with older age and higher basic wood density have higher quality for energy use. It can be concluded that the cluster analysis was adequate to efficiently stratify regions and ages with higher and lower productivity, as well as those with better energetic properties. Keywords: Multivariate techniques, forestry production, similarity groups.

\section{INTRODUCTION}

The preference for fast-growing species and the diversity of wood uses underscore the importance of the Eucalyptus genus in Brazil, as well as the prominence of silvicultural practices, evolution of technologies and forest management were fundamental for the forest sector growth and consolidation of eucalyptus culture. The growing interest in the use of forest biomass for energy production, as it is a renewable source, is no longer seen as just another use for wood and become one of the forest business areas.

The suitability of a species for energy use, in addition to the basic density of wood, it is essential to know the behavior of the energetic properties of the material, such as calorific value, volatile material content, fixed carbon and ash, in order to guarantee an efficient use of the resource.

When there is a large number of information and variable responses (attributes), multivariate techniques can be used to simplify the data set and facilitate the understanding between these attributes. Factor Analysis (FA) allows to represent the behavior of a relatively large number of observed variables, in a relatively small number of latent variables or factors, and the variables are grouped by means of their correlations, that is, those belonging

FLORESTA, Curitiba, PR, v. 51, n. 1, p. 118-126, jan/mar 2021. 
to the same group will be strongly correlated, but weakly correlated with the variables of another group, and each group of variables represent a factor (BEEBE et al.,1998).

Principal Component Analysis (PCA) seeks to redistribute the variation in variables in order to obtain the orthogonal set of uncorrelated axes. In practice, most of the data variability can be explained by a smaller number of main components (FERREIRA, 2008).

Cluster analysis (CA) aims to propose a classificatory structure, or to recognize the existence of groups, which can be applied to verify the existence of similar behaviors between variables (FÁVERO; BELFIORE, 2015). One of the characteristics of the clusters is high internal homogeneity and high external heterogeneity, between clusters (HAIR et al., 2005). In the several areas of forest sciences the use of multivariate techniques has been very efficient in data analysis, highlighting the use of analysis of the main components and groupings for assessing the energetic properties of wood, forest biomass and charcoal (CASTRO et al., 2013; PROTÁSIO et al., 2013).

For energy production, some important information must be considered such as physical and energetic properties, age of the population, productivity and these can vary depending on the forest production region. Therefore, the objective was to find groups with similarity between dendrometric variables and energetic properties for different regions and ages of production of Eucalyptus benthamii Maiden et Cambage, through multivariate analyzes.

\section{MATERIAL AND METHODS}

The data used came from forest stands of E. benthamii implanted in the Municipality of Guarapuava-PR. For the dendrometric variables, it was used information from a continuous forest inventory of E. benthamii plantations at different ages (5, 6 and 7 years) and different regions of commercial plantations (R1, R2 and R3), from permanent rectangular plots with an area of $500 \mathrm{~m}^{2}$. The sampling intensity represents $1 \%$ of the area, with an average of 1 plot per 5 hectares. The spacing adopted in these plantations is $2.5 \times 2 \mathrm{~m}$.

After obtaining forest inventory information of the areas and ages selected for the study, values of diameter at breast height $(\mathrm{DBH})$ were grouped into classes of diameter, considering the lower and upper limits of each age and indicating the number of diameter classes by the Sturges formula:

$$
K=1+3.33 \cdot \log (n)
$$

where: $\mathrm{K}=$ number of classes and $\mathrm{n}=$ number of observations.

The class center was considered the average between the lower and upper limits of each diameter class. The trees used for cubing and later for the volumetric equations and determination of wood properties are listed in Table 1.

Table 1. Diameter of $E$. benthamii trees sampled at each age and region Tabela 2. Diâmetro das árvores de E. benthamii amostradas em cada idade e região

\begin{tabular}{c|c|c|c|c|c|c|c|c|c}
\hline \multirow{2}{*}{$\begin{array}{c}\text { Class center } \\
(\mathbf{c m})\end{array}$} & \multicolumn{3}{|c|}{$\mathbf{5}$ years } & \multicolumn{3}{c|}{ 6 years } & \multicolumn{3}{c}{$\mathbf{7}$ years } \\
\cline { 2 - 10 } $\mathbf{4}$ & $\mathbf{R 1}$ & $\mathbf{R 2}$ & $\mathbf{R 3}$ & $\mathbf{R 1}$ & $\mathbf{R ~ 2}$ & $\mathbf{R ~ 3}$ & $\mathbf{R ~ 1}$ & $\mathbf{R 2}$ & $\mathbf{R 3}$ \\
\hline \multirow{3}{*}{$\mathbf{1 1}$} & 5.4 & 5.6 & 5.6 & 5.9 & 5.1 & 6.0 & 5.6 & 6.0 & 5.6 \\
& 7.0 & 8.0 & 6.7 & 7.3 & 6.4 & 7.6 & 7.0 & 7.6 & 6.4 \\
& 8.0 & 8.8 & 8 & 8.3 & 7.0 & 8.9 & 8.3 & 8.6 & 6.4 \\
\hline \multirow{3}{*}{$\mathbf{1 5}$} & 10.5 & 9.9 & 10.2 & 10.5 & 8.9 & 9.9 & 9.7 & 9.5 & 9.3 \\
& 11.1 & 11.3 & 11.5 & 11.3 & 10.2 & 11.1 & 10.0 & 11.0 & 9.3 \\
& 12.1 & 12.1 & 12.4 & 12.4 & 11.8 & 12.4 & 11.4 & 11.5 & 10.3 \\
\hline \multirow{3}{*}{$\mathbf{1 9}$} & 14.3 & 13.8 & 13.4 & 13.1 & 13.4 & 13.7 & 13.6 & 14.3 & 13.1 \\
& 14.8 & 15.0 & 15.1 & 14.7 & 14.3 & 15.6 & 14.8 & 16.0 & 13.9 \\
& 16.5 & 16.2 & 16.7 & 15.6 & 15.3 & 16.9 & 16.0 & 17.0 & 15.3 \\
\hline \multirow{2}{*}{$\mathbf{2 3}$} & 17.5 & 17.5 & 17.8 & 17.3 & 17.2 & 18.1 & 17.5 & 17.6 & 17.8 \\
& 18.5 & 17.5 & 18.8 & 18.1 & 18.3 & 19.4 & 18.9 & 19.5 & 18.6 \\
& 19.7 & 20.1 & 20.4 & 19.4 & 20.1 & 20.7 & 20.7 & 20.7 & 20.4 \\
\hline
\end{tabular}


The estimated dendrometric variables were average diameter $(\mathrm{DBH})$, average height $(\mathrm{H})$, number of trees per hectare (N/ha), basal area $(\mathrm{G})$, individual volume (v) average annual increment (IMA) and production at each age and region $(\mathrm{V})$, using continuous forest inventory measurements to calculate the estimates.

The estimate of average annual increment in dry mass was obtained by multiplying the average annual increment by the weighted average basic density of the tree $\left(\mathrm{kg} \mathrm{m}^{-3}\right)$, determined in each age and region.

\section{Basic density and energy density}

For wood analysis, five discs were removed from each tree, at heights corresponding to $0 ; 1.30 \mathrm{~m} ; 25 \%$; $50 \%$ and $75 \%$ of the total height of the tree. Opposite wedges were marked for each disk, which were used to determine the basic density that followed the method adapted from the ASTM D2395-14 standard (AMERICAN SOCIETY FOR TESTING AND MATERIALS, 2009), the result being presented in the weighted form by volume.

The energy density was calculated by multiplying the average values of basic density (BD) and higher calorific value (HCV).

Immediate chemical analysis and calorific value

The immediate chemical composition was determined based on the adaptation of the ASTM D1762-84 standard (AMERICAN SOCIETY FOR TESTING AND MATERIALS, 2013) performed with samples composed of milled wood in a Willey mill, which represents the minimum, medium and maximum diametric classes, using three samples in each class, totaling 27 samples.

The determination of the superior calorific power was performed with $3 \mathrm{~g}$ samples, in an adiabatic calorimetric pump model IKA-WERNE C5000, based on the ASTM D5865-13 standard (AMERICAN SOCIETY FOR TESTING AND MATERIALS, 2013). The lower calorific value, that is, the total available energy, was calculated based on the HCV and the average hydrogen content $(6 \%)$..

Factor analysis (FA), principal component analysis (PCA) and cluster analysis (CA)

Factor analyzes were performed to reduce the data dimensionality for dendrometric variables: diameter at breast height $(\mathrm{DBH})$, average height $(\mathrm{H})$, individual volume $(\mathrm{v})$, volume per hectare $(\mathrm{V})$, average annual increment (AAI), increase in dry mass (IDMBD) and energetic variables: basic density (BD), energy density (ED), volatile materials (VM), ash content (AC), fixed carbon (FC), higher calorific value (PCS) and lower calorific value (LCV).

In each analysis performed, we sought the attributes that represented the highest percentage of the explained variance, without losing information. Communality values $\geq 0.7$ were considered, for a better interpretation of the groupings of the variables in the factors, the criterion of orthogonal rotation of the varimax raw factors was used. The attributes selected in the factor analysis were used in the subsequent analyzes: principal component analysis (PCA) and cluster analysis (CA). Both for factor analysis and principal components analysis considered the factors/major components with eigenvalues greater than 1.0.

In the cluster analysis (CA), the hierarchical clustering technique was used, using the Ward method (minimum variance), considering the Euclidean distance between treatments. The analyzes were performed using the STATISTICA software.

\section{RESULTS}

Table 2 shows the average values of the dendrometric properties observed for the regions and ages evaluated. The mean values were $13.2 \mathrm{~cm}$ for the DBH, $19.8 \mathrm{~m}$ for height and $24.34 \mathrm{~m}^{2} \mathrm{ha}^{-1}$ for the basal area. The best value of the average annual increment was evaluated for region 3 at 5 and 6 years, followed by region 1 at 5 years $\left(53.82 \mathrm{~m}^{3}\right.$ ha year $\left.{ }^{-1}\right)$ and region 2 with $43 \mathrm{~m}^{3}$ ha year ${ }^{-1}$. The most productive region, when the total volumetric production by area was evaluated, was region 3 at 6 years old, with $327.34 \mathrm{~m}^{3} \mathrm{ha}^{-1}$.

Region 3 for the age of 6 years, presented the highest values of dendrometric variables, except for N/ha, contributing to the greater volumetric production and increase in dry mass $\left(22,696 \mathrm{~kg}\right.$ ha year $\left.{ }^{-1}\right)$, an important factor when analyzing the production for energetic purposes.

Table 2. Dendrometric variables and increase in dry mass for E. benthamii as a function of age and sampling regions.

Tabela 2. Variáveis dendrométricas e incremento em massa seca para E. benthamii em função das idades e regiões de amostragem.

FLORESTA, Curitiba, PR, v. 51, n. 1, p. 118-126, jan/mar 2021. 


\begin{tabular}{cccccccccc}
\hline Region & Age & DBH & H & N/ha & G & v & V & AAI & IDMBD \\
\hline \multirow{3}{*}{ R1 } & 5 & 12.55 & 19.95 & 1,763 & 24.80 & 0.1571 & 268.82 & 53.82 & 21,841 \\
& 6 & 12.84 & 19.53 & 1,680 & 25.72 & 0.1725 & 265.06 & 44.18 & 18,600 \\
& 7 & 13.55 & 20.33 & 1,663 & 27.51 & 0.1843 & 311.89 & 44.18 & 20,720 \\
\hline \multirow{3}{*}{ R2 } & 5 & 12.13 & 19.14 & 1,660 & 20.71 & 0.1337 & 219.58 & 43.79 & 18,136 \\
& 6 & 12.90 & 19.53 & 1,620 & 24.65 & 0.1481 & 241.14 & 40.18 & 17,119 \\
& 7 & 14.12 & 19.98 & 1,412 & 26.77 & 0.2156 & 307.91 & 43.98 & 18,957 \\
\hline \multirow{3}{*}{ R3 } & 5 & 13.57 & 19.95 & 1,508 & 24.94 & 0.1816 & 273.84 & 54.76 & 22,289 \\
& 6 & 15.32 & 21.63 & 1,620 & 30.85 & 0.2128 & 327.34 & 54.54 & 22,696 \\
& 7 & 12.06 & 18.78 & 1,468 & 19.11 & 0.1819 & 268.00 & 39.04 & 16,475 \\
\hline
\end{tabular}

Legend: $\mathrm{DBH}=$ Average diameter at breast height $(\mathrm{cm}) . \mathrm{H}=$ Average height $(\mathrm{m}) . \mathrm{N} / \mathrm{ha}=$ Number of trees per hectare. $\mathrm{G}=\mathrm{Basal}$ area per hectare $\left(\mathrm{m}^{2}\right.$ ha $\left.{ }^{-1}\right) . \mathrm{v}=$ individual volume $\left(\mathrm{m}^{3} \mathrm{arv}^{-1}\right) . \mathrm{V}=$ volume in one hectare $\left(\mathrm{m}^{3} \mathrm{ha}^{-1}\right)$. AAI $=$ average annual increment $\left(\mathrm{m}^{3}\right.$ ha ano $\left.{ }^{-1}\right)$. IDMBD $=$ Increase in dry mass based on average basic density $\left(\mathrm{kg}_{\mathrm{g}} \mathrm{ano}^{-1}\right)$.

Table 3 shows the average values for the physical and energetic properties of E. benthamii wood. The highest value of basic wood density was observed in region 1 at 7 years of age $\left(0.47 \mathrm{~g} \mathrm{~cm}^{-3}\right)$. The three regions evaluated showed higher values of basic density according to their older age. The volatile material values of $E$. benthamii ranged from 85.55 to $88.08 \%$, the fixed carbon content from 12.10 to 13.93 and the ash content from 0.30 to $0.48 \%$. The average calorific value was $4,444 \mathrm{Kcal} \mathrm{kg}^{-1}$ and the lower $4,237 \mathrm{Kcal} \mathrm{kg}^{-1}$. The behavior of energy density followed the same trend as basic density, in which the highest value was recorded for region 1 at the age of 7 years and the lowest for region 3 at the age of 5 years. This is due to the increase in energy density proportional to the basic density..

Table 3. Physical, chemical and energetic properties for E. benthamii, according to age and sampling regions.

Tabela 3. Propriedades físicas, químicas e energéticas para E. benthamii, em função das idades e regiões de amostragem.

\begin{tabular}{ccccccccc}
\hline Region & Age & BD & VM & FC & AC & HCV & LCV & ED \\
\hline \multirow{2}{*}{ R1 } & 5 & 0.42 & 86.33 & 13.35 & 0.3 & 4,481 & 4,193 & 1,937 \\
& 6 & 0.43 & 85.55 & 13.93 & 0.48 & 4,591 & 4,269 & 1,971 \\
& 7 & 0.47 & 87.68 & 12.1 & 0.3 & 4,534 & 4,226 & 2,131 \\
\hline \multirow{2}{*}{ R2 } & 5 & 0.41 & 86.63 & 12.9 & 0.44 & 4,589 & 4,269 & 1,906 \\
& 6 & 0.42 & 85.82 & 13.28 & 0.48 & 4,504 & 4,198 & 1,928 \\
& 7 & 0.43 & 87.01 & 12.63 & 0.35 & 4,585 & 4,266 & 1,934 \\
\hline \multirow{2}{*}{ R3 } & 5 & 0.41 & 88.08 & 11.43 & 0.47 & 4,564 & 4,241 & 1,837 \\
& 6 & 0.42 & 85.82 & 13.72 & 0.43 & 4,605 & 4,282 & 1,871 \\
& 7 & 0.43 & 86.69 & 12.92 & 0.36 & 4,505 & 4,192 & 1,881 \\
\hline
\end{tabular}

Legend: $\mathrm{BD}=$ Basic density weighted by volume $\left(\mathrm{g} \mathrm{cm}^{-3}\right) . \mathrm{VM}=$ Volatile materials $(\%)$. FC = Fixed carbon content $(\%)$. AC $=$ Ash content $(\%) . \mathrm{HCV}=$ Higher calorific value $\left(\mathrm{Kcal} \mathrm{kg}^{-1}\right) . \mathrm{LCV}=$ Lower calorific value $\left(\mathrm{Kcal} \mathrm{kg}^{-1}\right) . \mathrm{ED}=$ Energy density $\left(\mathrm{Mcal}^{\mathrm{m}} \mathrm{m}^{-3}\right)$.

Factor analysis and main componentes

The explained variance and the values for each eigenvalue for both factor analysis and principal component analysis are shown in Table 4. It was observed that the variance explained by the first factor (or first main component) was $61.71 \%$ and the total variance explained by the first 2 factors was $95.22 \%$. The eigenvalues were 3.08 and 1.67 , respectively, for the first and second components.

Table 4. Summary of the variance explained by two factors selected in the factor analysis and principal components.

Tabela 4. Resumo da variância explicada pelos dois fatores selecionados na análise fatorial e componentes principais. 


\begin{tabular}{cccc}
\hline & \multicolumn{3}{c}{ Variance explained } \\
\cline { 2 - 4 } Components or factors & Eigenvalue & Variance (\%) & Accumulated variance (\%) \\
\hline $\mathbf{1}$ & 3.08 & 61.71 & 61.71 \\
$\mathbf{2}$ & 1.67 & 33.51 & 95.22 \\
\hline
\end{tabular}

The maintenance of 2 factors allowed to measure the relationship and explanation of the variables capable of evaluating the production and properties of E. benthamii (Table 5). The commonality for the attributes selected by the factor analysis are between 0.8588 and 0.9908 (Table 5).

Table 5. Attributes, factor loads for the two selected factors and commonalities.

Tabela 5. Atributos, cargas fatoriais para os dois fatores selecionados e comunalidades.

\begin{tabular}{lccc}
\hline Attributes & Factor 1 & Factor 2 & Commonalities \\
\hline DBH $(\mathrm{cm})$ & $\mathbf{0 . 9 9 5 4}$ & 0.0017 & 0.9908 \\
$\mathrm{BD}\left(\mathrm{g} \mathrm{cm}^{3}\right)$ & 0.0798 & $\mathbf{0 . 9 9 1 3}$ & 0.9889 \\
$\mathrm{ED}\left(\mathrm{Mcal} \mathrm{m}^{-3}\right)$ & 0.1481 & $\mathbf{0 . 9 8 1 4}$ & 0.9851 \\
$\mathrm{H}(\mathrm{m})$ & $\mathbf{0 . 9 6 0 4}$ & 0.1213 & 0.9371 \\
$\mathrm{~V}\left(\mathrm{~m}^{3} \mathrm{ha}^{-1}\right)$ & $\mathbf{0 . 8 6 2 1}$ & 0.3400 & 0.8588 \\
\hline
\end{tabular}

The main component 1 , divided the treatments with high values for $\mathrm{BD}, \mathrm{ED}, \mathrm{V}, \mathrm{H}$ and $\mathrm{DBH}$ that are allocated on the left side of the " $x$ " axis (Figure 1A) and represent 61, 71\% of the explained variance. PCA showed the formation of three large groups. The first group showed high values of DB and DE (Figure 1B), highlighting the region R1-I7 that presented the highest values for these attributes.
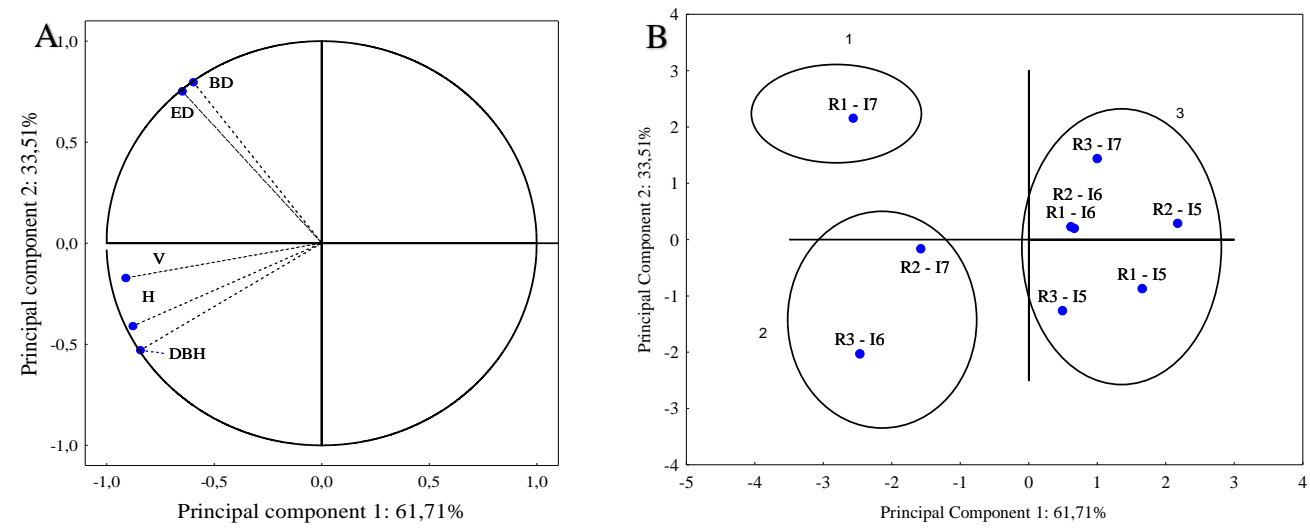

Figure 1. A. Graphical representation of PCA weights for dendrometric attributes, basic and energetic density of E. benthamii. B. Graphical representation of PCA scores for dendrometric attributes and energetic properties of E. benthamii.

Figura 1. A. Representação gráfica de pesos de ACP para atributos dendrométricos e de densidade básica e energética de E. benthamii. B. Representação gráfica dos escores de ACP para atributos dendrométricos e de propriedades energéticas de E. benthamii.

A second group formed by PCA showed a high correlation between the attributes of V $(0.75), \mathrm{H}(0.75)$ and DBH (0.97). The treatments that were allocated in this group were the R2 and R3 regions with 7 and 6 years of age, respectively. The third group formed by treatments from regions R1 with 5 and 6 years of age, region R 2 with 5 and 6 years of age and by region R3 with individuals from 5 and 7 years of age had the lowest values of dendrometric and energetic properties of E. benthamii.

In the same way as the principal component analysis, the hierarchical cluster analysis showed the basic formation of two large groups (Figure 2), a group formed by the properties of wood and another group formed by the dendrometric properties of $E$. benthamii.

Cultivation regions under their respective ages were also submitted to CA and are represented in Figure 3. Observing the dendrogram, considering a cut between the connection distance between 4 and 5, the formation of

FLORESTA, Curitiba, PR, v. 51, n. 1, p. 118-126, jan/mar 2021.

Benin, C. C. et.al.

ISSN eletrônico 1982-4688

DOI: $10.5380 /$ rf.v51 i1. 67423 
two groups of high similarity stands out. Group $1(\mathrm{G} 1)$ is formed by the R1, R2 regions aged 7 years and the R3 region aged six years. This group is represented by the highest values both for volumetric production and for the properties that represented the highest energy efficiency.

Group 2 (G2) is composed of different ages and different regions, which have similar characteristics in terms of dendrometric properties, basic density and energy density. This group is formed by the regions R1 and R2 with 6 years old, region R2 with 5 years old and region R3 with 7 years old. Also, in this large group (G2) a subgroup was formed comprising the regions R1 and R3 with 5 years of age. The hierarchical cluster analysis was important to confirm the groups related to the energy and dendrometric properties of E. benthamii, identified in the analysis of main components.

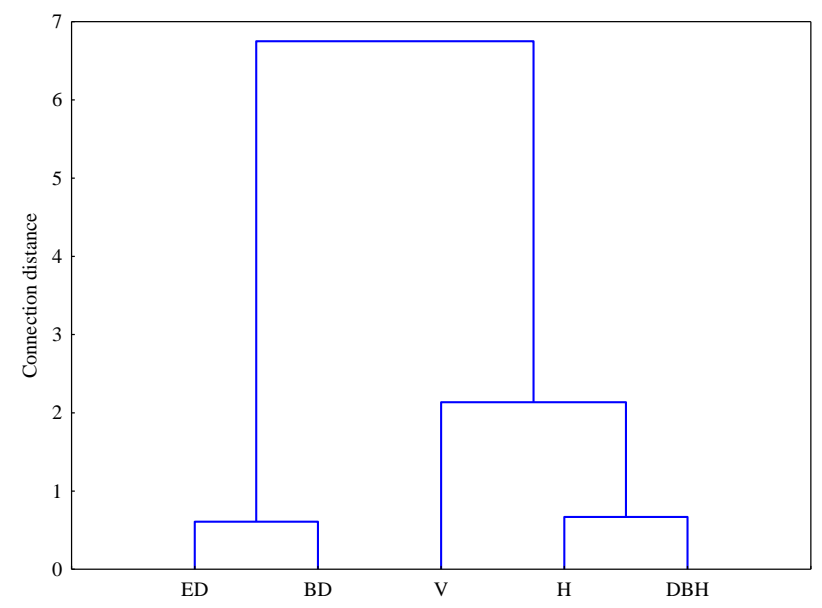

Figure 2. Dendrogram and groups according to the properties evaluated for E. benthamii from the cluster analysis. Figura 2. Dendrograma e grupos de acordo com as propriedades avaliadas para E. benthamii, a partir da análise de agrupamentos.

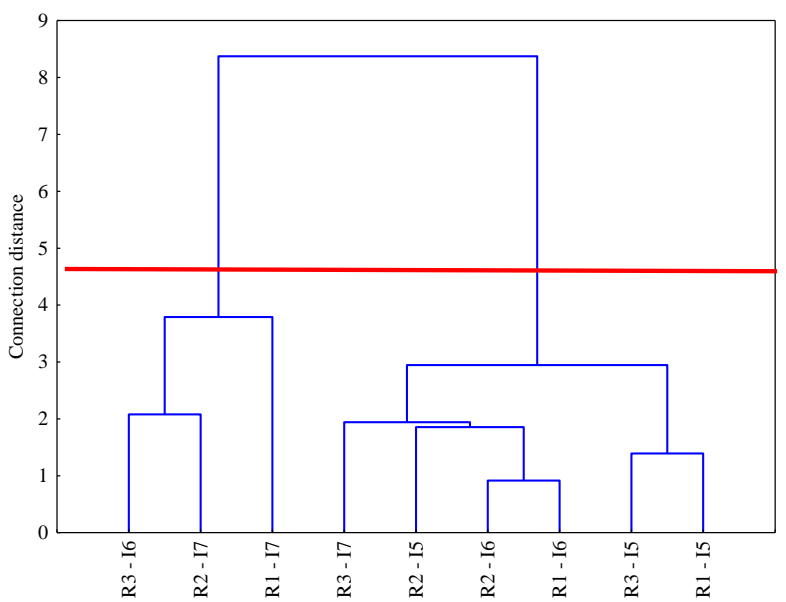

Figure 3. Dendrogram by Ward's method for regions and ages in the management of E. benthamii. Highlight for the level of cut (horizontal red line) in the formation of groups.

Figura 3. Dendrograma pelo método de Ward para regiões e idades no manejo de E. benthamii. Destaque para nível de corte (linha vermelha horizontal) na formação de grupos

\section{DISCUSSION}

Dendrometric variables and dry mass

Regarding the variables of diameter at breast height and height, the average results were lower than those recorded by Vidaurre et al. (2015) in which they observed for E. benthamii at five years of age, in experimental conditions, values of diameter between 16.98 to $23.13 \mathrm{~cm}$ and 22.71 to $23.87 \mathrm{~m}$ for total height, as a function of smaller to wider spacing, respectively. In this study, because it is about average information on forest stands, the

FLORESTA, Curitiba, PR, v. 51, n. 1, p. 118-126, jan/mar 2021. 
values may have resulted from the negative influence of thin and dominated trees present in the stand. When evaluating the basal area, depending on the factors evaluated in this study, the variation found can be explained by the factors that affect this property, which according to Schneider (1993) is the average diameter and number of individuals per unit area (N/ha), which were lower in some regions and ages.

For the average annual increment, the values found were close to the results of Serpe et al. (2018a), whose registered value was $49.2 \mathrm{~m}^{3}$ ha year-1 at age six, for the average fertilization treatments used for E. benthamii, in experimental planting in the region of General Carneiro -PR.

The values found for the dry mass, corroborate with the study by Meneses et al. (2015), in which the effect of five ages (5, 6, 7, 8 and 9 years) and the site on the basic density and dry mass production for Eucalyptus urophylla S.T. Blake with an interest in its energetic properties. The authors stated that basic density and growth characteristics were significantly influenced by productive capacity, age and the interaction of these factors, as well as age positively influenced the dry mass production of wood in the evaluated places. In the evaluation of different genetic materials of Eucalyptus sp. regarding energetic properties, Carneiro et al. (2014) evaluated three clones at four different ages: 3, 4, 5 and 7 years and observed the positive effects of age on the basic density of the wood and, consequently, the amount of energy stored per $\mathrm{m}^{3}$ (based on dry mass).

Basic density and energetic properties

According to Sette Junior et al. (2012), the increase in the basic density value with the advancing age of the tree, is due to the beginning of the late wood, where it is observed an increase in the cell wall thickness and a reduction in the frequency of the vessel elements. Soares et al. (2015) also observed an increase in basic density as thetrees maturity of the E. grandis x E. urophylla hybrid increased, which were $0.33 \mathrm{~g} \mathrm{~cm}^{-3}, 0.44 \mathrm{~g} \mathrm{~cm}^{-3}$, and $0.54 \mathrm{~g} \mathrm{~cm}^{-3}$, for the ages of 3,5 and 7 years respectively. For E.benthamii at six years of age, the basic density recorded in a study carried out in the region of Guarapuava-PR, presented values between 0.47 to $0.52 \mathrm{~g} \mathrm{~cm}^{-3}$ (BENIN et al., 2017). Silva et al. (2015) found a basic density of $0.47 \mathrm{~g} \mathrm{~cm}^{-3}$ for E. benthamii trees collected in the region of Cerro Negro - SC. At 5 and 13 years of age, the values for basic density of E. benthamii in the region of Cerro Negro - SC, were 0.44 and $0.50 \mathrm{~g} \mathrm{~cm}^{-3}$, respectively (NONES et al., 2015). Alves et al. (2011) and Lima et al. (2011), found at the age of six, in the region of Guarapuava-PR, an average basic density of $0.47 \mathrm{~g} \mathrm{~cm}^{-}$ ${ }^{3}$ for $E$. benthamii.

Regarding energetic properties, the studies carried out by Silva et al. (2015) and Nones et al. (2015) with E. benthamii also found values of volatile materials above $80 \%$, fixed carbon content above $12 \%$ and ash content below $0.5 \%$, attesting to the species potential for energy purposes.

The average values of upper and lower calorific value were close to those found by Silva et al. (2015), which resulted in 4,679 kcal kg-1 for $\mathrm{HCV}$ and $4379 \mathrm{kcal} \mathrm{kg}^{-1}$ for LCV, for the same species in samples collected in the region of Cerro Negro-SC. Lima et al. (2011) in their research found HCV of $4681 \mathrm{kcal} \mathrm{kg}^{-1}$ in the region of Guarapuava - PR, at six years of age. When compared to the results by Nones et al. (2015), who found HCV of $4,067 \mathrm{kcal} \mathrm{kg}^{-1}$ and 4,194 kcal kg-1 , for E. benthamii at 5 and 13 years old, respectively, the values of the present study are higher.

The trend towards higher values of energy density according to the higher values of basic density was also observed in the study by Jesus et al. (2017), who concluded that the energy density of wood from different species of Eucalyptus increased proportionally to the basic density, and species classified as more dense showed a greater amount of available energy.

Factorial and cluster analysis

According to the graphical scores representation, the R1 region at the age of 7 years is related to a wood producing region with high values of basic density and consequently will produce biomass with good energy performance, since the energy density brings intrinsic to its value the higher calorific value (LIMA et al., 2011). Protásio et al. (2013) observed the properties of wood for energy purposes and carbon stock for some E.urophylla clones and using multivariate techniques, identified that among the materials evaluated, clones U059 and U221 stood out for the generation of bioenergy, due to the high values of basic and energy density. For energy use of E. benthamii, from the properties evaluated at six years of age, Lima et al. (2011) observed through the analysis of main components, that the mass, volume and energetic potential of the wood are the main variables to be considered for selection of individuals or plantations for this purpose.

Regarding the second group represented in Figure 1A, which showed a high correlation between dendrometric variables, the result was consistent with the results of initial evaluations of E. benthamii at 2 and 3 years in the region of Guarapuava-PR, in which the authors identified high values of correlations between DBH and $\mathrm{V}$, and the values increased according to age (BENIN et al., 2014).

In relation to Figure 3, which represents the similarity groups, it was possible to confirm the positive effect of age, for volumetric production and for basic density, corroborating what was observed in the study by Carneiro

FLORESTA, Curitiba, PR, v. 51, n. 1, p. 118-126, jan/mar 2021.

Benin, C. C. et.al.

ISSN eletrônico 1982-4688

DOI: $10.5380 /$ rf.v51 i1. 67423 
et al. (2014) that when evaluating the energetic potential of genetic materials as a function of age, they observed in the older ages better values of basic wood density and, consequently, greater amount of energy stored per $\mathrm{m}^{3}$. This observation is reinforced by the fact that with increasing age of the trees occur transformations of chemical, physical, and anatomical on wood (PROTASIO et al, 2014), reflecting the increase in value of evaluated properties, for example in basic density.

On the use of multivariate techniques and their efficiency in the selection of interest groups for energy purposes, Protásio et al. (2013) used multivariate analysis techniques in order to select Eucalyptus clones for the production of charcoal and bioenergy, concluding the efficiency of this technique and the possibility of selecting genetic materials related to the studied properties. Franzen et al. (2018) stated that cluster analysis was a useful tool and made it possible to classify native species in the Amazon based on their technological characteristics, showing their similarity between them and directing the use of these species according to their physical-chemical characteristics.

\section{CONCLUSIONS}

- Multivariate analyzes of main components with factorial and groupings by the hierarchical method proved to be efficient in discriminating two groups with similarity to each other, sufficient to describe the volume production and the energetic properties of E. benthamii, in the areas of interest of this study;

- From the groups identified in the dendrograms, it was possible to confirm more productive regions and ages for the production of E. benthamii for energy purposes, which are: R1-I7; R2-I7 and R3-I6.

\section{REFERENCES}

ALVES, I. C. et al. Caracterização tecnológica da madeira de Eucalyptus benthamii para a produção de celulose Kraft. Ciência Florestal, Santa Maria, v. 21, n. 1, p. 167-174, 2011.

ASTM - AMERICAN SOCIETY FOR TESTING AND MATERIALS. "D5865-13: Standard Test Methods for Gross Calorific Value of Coal and Coke by the Adiabatic Bomb Calorimeter". Annual Book of ASTM Standards, 2013.

ASTM - AMERICAN SOCIETY FOR TESTING AND MATERIALS. "D2395 - 14: Standard Test Methods for Density and Specific Gravity (Relative Density) of Wood and Wood-Based Materials". West Conshohocken: ASTM International, 2009.

ASTM - AMERICAN SOCIETY FOR TESTING MATERIALS. "D1762-84: Standard method for chemical analyses of wood charcoal". Philadelphia, 2013.

BENIN, C.C.; WIONZEK, F.B.; WATZLAWICK, L.F. Initial assessments on the plantation of Eucalyptus benthamii Maiden et Cambage deployed in different spacing. Brazilian Journal of Applied Technology for Agricultural Science, Guarapuava, v.7, n.1, p.55-61, 2014.

BENIN, C.C.; WATZLAWICK, L.F.; HILLIG, E. Propriedades físicas e mecânicas da madeira de Eucalyptus benthamii sob efeito do espaçamento de plantio. Ciência Florestal, Santa Maria, v. 27, n. 4, p. 1375-1384, 2017.

BEEBE, K. R.; RANDY, J. P.; SEASHOLTZ, M. B. Chemometrics: A practical guide, New York: WileyInterscience, 1998, 520p.

CASTRO, A. F. N. M.; CASTRO, R. V. O.; CARNEIRO, A. C. O.; LIMA, J. E.; SANTOS, R. C.; PEREIRA, B. L. C.; ALVES, I. C. N. Análise multivariada para seleção de clones de Eucalipto destinados à produção de carvão vegetal. Pesquisa Agropecuária Brasileira, Brasília, v. 48, n. 6, p. 627-635, 2013.

CARNEIRO, A. C. O.; CASTRO, A. F. N. M.; CASTRO, R. V. O.; SANTOS, R. C.; FERREIRA, L. P.; DAMÁSIO, R. A. P.; VITAL, B. R. Potencial energético da madeira de Eucalyptus sp. em função da idade e de diferentes materiais genéticos. Árvore, Viçosa, v.38, n.2, p.375-381, 2014.

FÁVERO, L.P.; BELFIORE, P. Análise de Dados: Técnicas Multivariadas Exploratórias com SPSS e STATA. Rio de Janeiro: Editora Elsevier, $1^{a}$ ed. 2015, 368p.

FERREIRA, D.F. Estatística Multivariada. Lavras: UFLA, 2008, 662p.

FRANZEN, D. C.; MENDOZA, A. M dos S. H.; BORGES, P. H de M.; MADI, J.P.S.; BORGES, D. de S. Estudo das propriedades físicas e químicas de madeiras provenientes de espécies nativas da Amazônia legal. Enciclopédia biosfera, Goiânia, v.15 n.27, p. 498-509, 2018.

FLORESTA, Curitiba, PR, v. 51, n. 1, p. 118-126, jan/mar 2021. 
HAIR JUNIOR, J.F.; BLACK, W.C.; BABIN, B.J.; ANDERSON, R.E.; TATHAM, R.L. Análise multivariada de dados. Porto Alegre: Bookman, 2005, 600p.

JESUS, M.S de; COSTA, L.J.; FERREIRA, J.C.; FREITAS, F. P de; SANTOS, L.C.; ROCHA, M. F. V. Caracterização energética de diferentes espécies de Eucalyptus. Floresta, Curitiba, v. 47, n. 1, p. 11-16 2017.

LIMA, E. A.; SILVA, H. D.; LAVORANTI, O. J. Caracterização dendroenergética de árvores de Eucalyptus benthamii. Pesquisa Florestal Brasileira, Colombo, v. 31, n. 65, p. 09-17, 2011.

MENESES, V.A., TRUGILHO, P.F., CALEGARIO, N.; LEITE, H.G. Efeito da idade e do sítio na densidade básica e produção de massa seca de madeira em um clone do Eucalyptus urophylla. Scientia Forestalis, Piracicaba, v. 43, n. 105, p. 101-116, 2015.

NONES, D.L.; BRAND, M.A.; CUNHA, A.B da.; CARVALHO, A.F de., WEISE, S.M.K. Determinação das propriedades energéticas da madeira e do carvão vegetal produzido a partir de Eucalyptus benthamii. Floresta, Curitiba, v. 45, n. 1, p. 57 - 64, 2015.

PROTÁSIO, T. de P.; COUTO, A. M.; REIS, A. A dos; TRUGILHO, P. F. Seleção de Clones de Eucalyptus para a produção de carvão vegetal e bioenergia por meio de técnicas univariadas e multivariadas. Scientia Forestalis, Piracicaba, v. 41, n. 97, p. 015-028, 2013.

PROTÁSIO, T. de P.; NEVES, T. A.; REIS, A. A dos; TRUGILHO, P. F. Efeito da idade e clone na qualidade da madeira de Eucalyptus spp visando à produção de bioenergia. Ciência Florestal, Santa Maria, v. 24, n. 2, p. 465477,2014

SERPE, E.L.; ARCE, J. E.; FIGUEIREDO FILHO, A.; LISBOA, G dos S.; STEPKA, T.F. Análise do comportamento de equações hipsométricas e afilamento para Eucalyptus benthamii Maiden et Cambage. Integrada,v. 5, n. 1, 2018a.

SETTE JUNIOR, C. R.; OLIVEIRA, I.R de; FILHO, M.T.; YAMAJI, F. M.; LACLAU, J.P. Efeito da idade e posição de amostragem na densidade e características anatômicas da madeira de Eucalyptus grandis. Árvore, Viçosa, v. 36, n. 6, p. 1183-1190, 2012.

SCHNEIDER, P. R. Introdução ao manejo florestal. Santa Maria: UFSM, 1993.348p.

SILVA, D. A. da; MULLER. B.V.; KUIASKI. E. L.; ELOY.E.; BEHLING.A.; COLAÇO, C.M. Propriedades da madeira de Eucalyptus benthamii para produção de energia. Pesquisa Florestal Brasileira, Colombo, v. 35, n. 84, p. 481-485, 2015.

SOARES, V.C., BIANCHI, M.L.; TRUGILHO, P.F., HOFLER, J.PEREIRA, A. J. Análise das propriedades da madeira e do carvão vegetal de híbridos de eucalipto em três idades. Cerne, Lavras, v. 21 n. 2. p. 191-197, 2015.

VIDAURRE, G. B.; NUTTO, L.; FRANÇA, F.J.M.; BRAZ, R.L.; WATZLAWICK, L. F.; MOULIN, J.C. Tensão de crescimento do lenho de Eucalyptus benthamii e sua relação com características dendrométricas em diferentes espaçamentos. Floresta e Ambiente, Seropédica, vol.22, n.3, p. 408-415, 2015. 